\title{
Katarzyna Jagodzińska
}

\section{Responsibility of Museums Towards Landscape: Discussion Based on Case Studies From Katowice, Kraków, and Warsaw}

\begin{abstract}
According to the Resolution no 1, adopted by the ICOM's General Assembly in 2016, "Museums have a particular responsibility towards the landscape that surrounds them, urban or rural". And thus, they should "manage buildings and sites of cultural landscape as 'extended museums', offering enhanced protection and accessibility to such heritage in closed relationship with communities". This document arises from new museology thinking developed in the 1970s and 1980s. In the article we discuss this newly "codified" responsibility illustrated with an example of four Polish museums Muzeum Śląskie in Katowice, Museum of King Jan III's Palace at Wilanów, Muzeum Podgórza and Ethnographic Museum in Kraków - with intention to examine strategies and positions museums adopt, and contexts that determining those actions. We conclude that museums must play active parts in societies and take actions regarding changes in the landscape that surrounds them. However, the ICOM resolution is only a signpost, and broader recognition of museums as subjects of discussion on urban and rural space is required.
\end{abstract}

Keywords: new museology, landscape, responsibility, ICOM resolution 
In 2019, thirty years have passed since publication of Peter Vergo's book The New Museology. It has been a seminal reading on new roles and responsibilities of museums, although largely criticised for its one-dimensional perspective ignoring multitude of approaches that developed in various corners of the globe as 'new museology'. A responsibility of museums towards landscape, which was recognised by the 2016 ICOM resolution, arises from new museology thinking developed in the 1970s and the 1980s.

The article discusses this newly "codified" responsibility illustrated with an example of four Polish museums, with intention to examine strategies and positions museums adopt, and contexts determining those actions. Regardless the outcome, we conclude that museums must play active parts in societies and take actions regarding changes in the landscape that surrounds them. However, the ICOM resolution is only a signpost, and broader recognition of museums as subjects of discussion on urban and rural space is required.

\section{Context of the new museology}

"Museums are democratising, inclusive and polyphonic spaces for critical dialogue about the pasts and the futures" (Museum definition 2019). This is the beginning of a new museum definition discussed at the ICOM's Extraordinary General Assembly, which took place in Kyoto, in September 2019. Although the definition was not adopted and discussion on the changes will be continued, it is a clear sign that museums see their responsibilities in a new dimension, more relevant for contemporary needs, expectations, and demands. The definition embraces a number of timely and topical words, characterizing current debates on contemporary condition of the world: participation, transparency, active partnership with and for communities, human dignity, social justice, global equality, and planetary wellbeing.

This definition grew from a ferment in the museum world that was stirred in the 1960s and led to the birth of the 'new museology'. Instrumental in coining the term was a 1972 UNESCO-ICOM round-table meeting in Santiago de Chile, when they discussed a role of museums in relation to social and economic needs of the modern-day society in Latin America (Davis 1999: 53; Brown, Mairesse 2018: 529-530). The term was not yet in use at that time, and a museum involved with community was then labelled 'an integrated museum'. The term 'new museology', according to Peter van Mensch (1995), was used in various places at numerous occasions as early as in the 1950s, then in the 1980s with formation of Muséologie Nouvelle et Expérimentation sociale (MNES, 1982) in France and the MINOM (International Movement for a New Museology, 1985), which is an international organization affiliated to ICOM, and culminating in 1989, in a book by Peter Vergo simply entitled The New Museology. In 1984, "Declaration of Quebec: Basic 
Principles for a New Museology" was adopted at the First International Workshop on Ecomuseums and the New Museology in Quebec organized by Pierre Mayrand. It emphasized that new museology:

is primarily concerned with community development, reflecting the driving forces in social progress and associating them in its plans for the future. ... It has become a way of bringing people together to learn about themselves and each other, to develop their critical faculties and express their concern to establish together a world which takes a responsible attitude towards its own intrinsic riches (Mayrand 2015: 116-117).

Book by Vergo came in fact late and its shortcomings regarding the geographical scope limiting discussions to the Anglophone world give the wrong impression that new museology is a brainchild of the British museology of the late 1980s. In 1999, Peter Davis in another seminal book Ecomuseums: A Sense of Place asked "whether new museology is still «new»". And admitted that: "Many of the demands identified in the early 1980s have been met, traditional barriers have been broken and new working practices instituted as museums have moved from the modern to the postmodern age. In today's museums most things are possible" (Davis 1999: 58).

That was over twenty years ago; over thirty, since publication of the Vergo's book, and around fifty since the new museology was actually born. The MINOM is still operating under its original name and the new museology is a fundament for new museum paradigms and strategies. The ecomuseum - coined in 1971 by Hugues de Varine - is one of the earliest ways of reading the new museology principles. Another milestone is the emergence of the paradigm of the post-museum, conceptualized by Eilean Hooper-Greenhill (2000) and further discussed by Janet Marstine (2006). The term appeared at the turn of the $21^{\text {st }}$ century to reflect new roles and responsibilities of museums in the ever-changing world. The postmuseum seeks to share power with communities, encourages active participation in museum discourse, redresses social inequalities (Marstine 2006: 19). It is again an umbrella for new concepts of museums. One of them is a 'mindful museum' coined by Robert R. Janes (2010), later developed into a 'museum activism' (Janes, Sandell 2019).

Robert R. Janes and Richard Sandell (2019: 18) stress that in the pursuit of higher attendance numbers and attention given to digital technology "the museum community is not responding to the world, be it climate change; species extinction, or social justice issues such as poverty and homelessness". Their book, however, discusses a handful of museums that follow the responsible way of management and programme activities in line with changes and demands of the new times. In this article, we argue that museums should also feel responsible for their landscapes and take actions towards their protection and management.

It is indicative that assumptions of contemporary activist museum, relations between a museum and its environment, and the whole debate on changing the museum definition initiated in 2017 by creating the ICOM Committee for 
Museum Definition, Prospects and Potentials, draw from the 1970s discussions in Latin America. Karen Brown and François Mairesse (2018: 531) remind that in the 1990s Europe was largely affected by the "commercial turn", which came together with focus on museum architecture, blockbuster exhibitions, and museum marketing, and the change in thinking towards social role of museums arrived in 2007 accentuated by financial crisis. Since then, the new museology assumptions seem to be timely and relevant, again.

\section{ICOM resolution as legitimacy for actions}

In 2016, the ICOM's General Assembly adopted the Resolution no 1 grounded on the idea that: "Museums are part of the landscape. They collect tangible and intangible testimonials linked to the environment. The collections forming part of their heritage cannot be explained without the landscape" (Resolutions 2016). Based on that, the ICOM recommends that: "Museums extend their mission from a legal and operational point of view and manage buildings and sites of cultural landscape as «extended museums», offering enhanced protection and accessibility to such heritage in closed relationship with communities" (Resolutions 2016).

Vice President of ICOM, Alberto Garlandini (2017: 172), commenting on the resolution, emphasized that museums have "new responsibilities to the communities they represent, to the territory from which their collections originate and to the landscapes surrounding them". Those responsibilities translate into commitment to manage cultural and natural heritage in a sustainable way and "to be attentive to the images and representations of the landscape" (Garlandini 2016: 174).

This resolution is clearly grounded in previous museum discussions regarding partnering communities, recognizing the landscape, and addressing topical issues. It also grew from discussions held on the forum of international institutions, regarding cultural and natural heritage and defining the term 'landscape', including the European Landscape Convention adopted by the Council of Europe in 2000 and the Recommendation on the Historic Urban Landscape adopted by UNESCO in 2011. The ICOM Resolution acknowledges that "Landscape is a highly complex network, defined by relationships between social and natural elements", and continues that:

Cultural Landscape incorporates not only the physical size of a territory, but also a wide range of intangible factors - from language to lifestyle; from religious belief to the different forms of social life; from technology to ways of life and production, as well as power relations and exchanges between generations (Resolutions 2016).

The resolution is not revolutionary, it rather organizes and seals the current directions of change, and offers museums legitimacy to operate in such an "extend- 
ed" way. We believe, it goes in line with activist awakening observed in various areas of life. Museums not only seek engagement of their public, they are engaging as well in a public debate, which may only be loosely related to their collections, but closely connected to their identities and interests.

\section{Subject and methodology}

In this article, we discuss the nature of museums' engagement in issues behind their walls, and address the following questions: 1) Why museums should be subjects, not objects of these discussions?, 2) What museums can actually do?, 3) Can they be successful?, and 4) What is the role of museums' social context in their new position? Our discussion is based on the example of four Polish museums, whose activities towards safeguarding their landscape can be considered as exemplary: the Muzeum Śląskie in Katowice, the Museum of Podgórze (branch of the Museum of Kraków), the Ethnographic Museum in Kraków, and the Museum of King Jan III's Palace at Wilanów. These museums represent various types and encompass an encyclopaedic museum, a local history museum, an ethnographic museum and a residence. They are all located in urban contexts, however, in each case the nature of the site is different - from a post-industrial context and degraded urban area to a historical city centre, park, and residential district.

Material for this article was collected partly within the scope of Katarzyna Jagodzińska's research project, devoted to participation and the post-museum, including study visits and a series of interviews (conducted 2018-2019) with museum directors, curators, leaders of the projects, as well as museum consultants and engaged members of communities. Melania Tutak is a curator of the Museum of Podgórze and previously she headed the Podgórze History House, which thanks to her activity joined by the local association PODGORZE.PL - metamorphosed into a museum. She offers a first-hand view on position of the Museum of Podgórze and sees activities of other museums from a practitioner's perspective.

\section{Raising an alarm to protect post-industrial context of the museum}

In early 2018, the Muzeum Śląskie in Katowice alerted the public that the twelveand eighteen-storey blocks planned in its immediate vicinity may visually disturb the character of the museum complex, being a combination of old postmining buildings from a turn of the $20^{\text {th }}$ century and contemporary architecture designed by the Austrian Riegler Riewe Architekten studio. 
Muzeum Śląskie is an encyclopaedic museum, which with its diverse collections builds a narrative about the Upper Silesia region. Since its inception in 1929, it operated in temporary locations. In 2003, the regional government took the initiative to adapt a recently closed "Katowice" Coal Mine for the museum. In 2006, an international architectural competition was announced for designing the main building and creating a concept of an entrance integrated with the existing architecture (Jagodzińska 2019a: 99-100). The successful tenderer proposed a combination of minimalist glass cubes (serving as skylights and ventilation) and the existing red brick mine buildings and mine shafts. All exhibition spaces in the new investment were hidden underground to keep the prominence of industrial past on the ground level. The jury found this solution exceptionally appealing. In justification of the verdict they wrote: "The descent to the underground level of the Museum emphasizes the connection between its collections and the mining history of Silesia, whereas the place of the black treasure hidden deep in the ground is occupied by treasures of culture and memory" (Muzeum Śląskie 2007) Minimalism and simplicity of the design, combined with increasingly popular post-industrial architecture, as well as the proximity of other cultural institutions and a chill-out area, turned this place into a strong regional brand [Illustration 1]. The museum was opened to the public in 2015.

The complex of Muzeum Śląskie is a part of the Culture Zone, which also includes new buildings of the Polish National Radio Symphony Orchestra and the International Congress Centre, and is arranged with walking paths, squares with benches, a hedge maze, a fountain (although unreasonably separated by two ground-level car parks). An area behind the mine complex, slightly smaller than the Culture Zone, was left as wasteland. In 2016, a private developer TDJ Estate announced their plans to build residential blocks on a purchased land plot and commissioned Medusa Group, a renowned architectural studio from Silesia, to design them. Prior to public presentation, an architect demonstrated the project to the director of the Muzeum Śląskie, Alicja Knast. Concerned about what she saw, Knast demanded a discussion on the vision of urban space in the centre of Katowice (Jagodzińska 2019b). At the beginning of 2018, Knast asked on Twitter whether the blocks planned by the TDJ "must cover what is, in fact, a certain symbolic frame, the cultural landscape of this city and pars pro toto the cultural landscape of this region?”. And she appealed: “(...) we need a debate. Debate on where we are going as a city and as a region. What we respect and what is not important to us" (Twitter of the Muzeum Sląskie 2018) [Illustration 2]. This action was followed by a year of meetings, discussions, letters, and interviews.

The new commercial investment consists of eight blocks of flats in two lines. The first one, based on a common two-storey car park, will have twelve floors, the second - eighteen. High-rise buildings will inevitably create an unwanted background. The museum argued that blocks of flats will obstruct the view of the historical architecture of the mine from several places in the city centre. The head 
architect of the estate, Przemo Łukasik, co-founder of the Medusa Group, believes the opposite: "Cities are changing, transforming and evolving. The best example is the Culture Zone itself and the life that is reviving the neighbourhood. I can't agree that our buildings obstruct the museum, even though they are constructed in the neighbourhood, they constitute a distant background" (Jagodzińska 2019b: 149).

Unfortunately actions taken by the museum - meetings and numerous letters addressed to the city authorities, public discussions, consultations with experts in urban planning and architects, conversations with the estate architect, calls for action addressed both to the general public and museum specialists - did not result in any change in the designed complex. The museum remained quite solitary in this struggle. It attempted to convince city officials to introduce height restrictions to the museum complex vicinity in the local spatial management plan for this district which was being finalised at that time. Unsuccessfully, as it is in the city interest to develop this area into a high-rise and dense residential quarter. A draft of the plan announced at the beginning of 2019 agreed to all building dimensions planned by the developer. Furthermore, behind the congress centre it allows 28 -storey buildings (up to 100 meters high) and a highest point of 140 meters!

\section{Supporting civic actions against changes in the district}

Museum of King Jan III's Palace at Wilanów is a 89 ha estate, including the palace, royal gardens, a lake, and the Morysin nature reserve. It constitutes a part of the Wilanów landscape formed by King Jan III and listed as a historical monument in 1965. In the 1960s, the museum was in danger of being excluded from the list of monuments, and already then it faced a need to speak of its cultural environment. Initially, it undertook independent activities, conducted talks with public administration, neighbours and specialists in various fields about protection of cultural and landscape values, and organized public debates; and then sought support from local associations. The aim was to obtain permanent legal protection for the complex of monuments, what was finally achieved in 2014, when the area was relisted as a historical monument.

In 2013, the area surrounding the palace and park complex has been threatened by dynamic expansion of residential estates; since then activities of the museum counteracting the pressure of developers have been supported by the Genius Loci Association (linked to the palace). When a large part of a huge housing district Miasteczko Wilanów [Wilanów Town] was built, a spatial management plan for the Foreground of the Wilanów Palace (the area in the immediate vicinity of the palace complex) was approved. This plan threatened historical surroundings of the palace, therefore, the museum set itself the goal of changing it, in coopera- 
tion with organizations and associations formed among the Miasteczko Wilanów residents.

The discussed area is Wilanów Beach, a part of the Foreground of the Wilanów Palace, located within the three axes leading to the palace. The local council allocated it for the future Local Centre (space for the local community) to be used as a place for mass events and a playground. This project brutally interferes with the immediate surroundings of the palace and disrupts tranquillity of the residents of Miasteczko Wilanów, suffering from scarcity of green areas. Residents, in turn, would opt for a park in this area, acting as a buffer zone for the palace complex. Demands of the museum coincided with the needs of the residents. Maciej Żołnierczuk, $\mathrm{PhD}$, a specialist in landscape protection at the museum, recalls that the beginnings of cooperation between the museum and local community were not easy. A common interest was first expressed in 2017 after the public consultation: "What kind of park instead of beach?" regarding creation of the Local Centre. Żołnierczuk comments,

The moment, when the museum mixed in with the crowd of residents, we began to work together, the barriers disappeared, and the residents became convinced that we have common goals and we are worth cooperating with. Thanks to our consistent activity, people participating in the consultations know that they have allies in us, and together we are going in the same "green" direction (Interview with Maciej Żołnierczuk 2019).

The construction of a shopping centre planned in the Foreground since 2016, was another serious threat to the historical surroundings of the palace. Concerning this matter, the museum's voice was again supported by the local community and this time also by the local authorities. Museum Director, Paweł Jaskanis (2016), emphasized that: "this type of aggressive service infrastructure introduces cognitive dissonance of the public and disrupts the process of aesthetic experience, which is one of the main reasons for visits to Wilanów". The museum, supported by the local community, actively worked for the surrounding area, e.g. by preparing its own proposal of a local spatial management plan. These activities and parallel actions of the local community have succeeded in changes in the architectural concept of the building, first time in 2018 and again in 2019. The project finally presented is called Green Terraces; it has smaller dimensions than the original concept and is filled with greenery.

Jaskanis concluded that "creating a common good, together with representatives of civil society, is the responsibility of cultural institutions. That is why the museum was involved with public consultations, formulating statements and issuing opinions" (Abramczyk 2016). It organized a series of activities raising awareness of the area significance and involving various entities - associations of Wilanów residents, organizations operating within the estate and councillors of various political options - to joint action, however, the museum was never a coordinator of these activities. The museum hosted seminars and expert debates, workshops for children and young people, but the consultations themselves 
took place outside the museum walls. The fact that in their postulates in struggle for greenery more and more residents of Wilanów put protection of the historical heritage (the park and palace in Wilanów) as one of its main goals, the museum considers its mission and social success. It is also indicative that on the Wilanów Przyszłości association of residents Facebook fanpage one can find thanks for joint actions addressed equally to activists and the museum director.

\section{Leaders of civic actions}

The Museum of Podgórze is a participatory branch of the Museum of Kraków. Its activity encompasses the district of Podgórze, former Królewskie Wolne Miasto Podgórze (Royal Free City of Podgórze), founded in 1784 by Joseph II, Holy Roman Emperor, and merged with Kraków in 1915. The museum was created as a bottom-up initiative - grew from the need of local district community, mostly members of the local PODGORZE.PL Society. The germ of the future museum was the Podgórze History House managed by Melania Tutak. During its ten years of activity, it gathered artefacts related to the district, stories, and, most of all, generated energy that finally managed to convince the city authorities to establish a museum. From the very beginning, the museum in Podgórze was to serve as a meeting centre for the local community, to be a place of integration, activation, and reflection not only about the history, but also about the present and future of Podgórze.

The museum is located in the historical St. Benedict Inn [Illustration 3], the first spot of independent Poland, liberated during the Kraków Liberation Campaign in 1918. Dilapidated and forgotten until recently, thanks to renovation and conversion into a museum, it became an important memorial and a sign of cultural awakening of this part of Kraków.

The museum is adjacent to a wasteland below the railway flyover, which brutally disfigured the area in 2015-2017. Feeling responsibility for this space, the museum took up the project of restoring landscape values and creating integrating spaces in the immediate vicinity of the museum. The overall aim is to restore this area for the city and its citizens by creating a park and providing a pedestrian and bicycle path between points of interest in the district. The museum reinforced by local communities represented mostly by the PODGORZE.PL Society, city activists and local authorities created an informal group called The Group at the Railway Junction and started negotiations with various entities - the city authorities, the Railway, which is the owner of the land, and the City Greenery Board.

At the museum headquarters, public consultations were organized with participation of residents, activists, city authorities, representatives of municipal institutions, and owners of the land. Supported by activists and local artists, the museum organized happenings that drew attention of the Municipality to the essence of 
the problem. The programme of activities encompassed joint tidying up the area under the railway junction, planting sunflowers [Illustration 4], botanical walks, and getting rid of an illegal parking lot. Students of the Faculty of Landscape Architecture of the Cracow University of Technology, as a part of their theses, made architectural design concepts for a future park.

The park, as it was expressed during public consultations, would help organise communication between Podgórze and its industrial part called Zabłocie, and offer a place of respite for residents (referred to as the green lungs of this area) in the vicinity of a busy intersection. The park was conceived as an axis connecting cultural institutions, starting from the Museum of Podgórze, to the Schindler's Factory, the MOCAK Museum of Contemporary Art in Kraków, the Glass and Ceramics Centre, and the Planet Lem Centre of Literature and Language (to be opened in 2023). All these functions would transform the chaotic post-industrial space into a quarter of culture.

The process is underway. The City Infrastructure Deputy Mayor, inspired by The Group at the Railway Junction, prompted actions taken by city officials. As a result, the Municipality secured financial resources in 2020 budget to prepare a development concept for the green space under the junction and a new pedestrian and cycling bridge between the railway bridges at Vistula river.

In the district of Kazimierz, the Ethnographic Museum also assumed the role of a leader of transformation in the direct vicinity of its headquarters. The situation is different, however, as this museum is a regional institution, unlike the Museum of Podgórze, which is funded by the Municipality. The Ethnographic Museum has two locations: the permanent exhibition is located in a former town hall of the district, while temporary exhibition space and the offices operate in a townhouse fifty metres away.

The town hall forms one of the frontages of Wolnica Square, the historical main market square of the district, dating back to the $14^{\text {th }}$ century. In the $19^{\text {th }}$ century it was halved and over time it lost its commercial function. For decades now, the square has been used as an event space, hosting festivals and various mass events. There is only a handful of benches and greenery, and thus it is seen as an unfriendly and unappealing space to spend time or relax (Jagodzińska 2020). At the beginning of 2019, the entire square became a parking space for the duration of major reconstruction of the main street running along the opposite side of the town hall [Illustration 5].

Residents and neighbours constantly call for humanization of this space. In 2009 , a competition was organized for an urban and architectural development concept for the square. The winning project by Lewicki Łatak Design Office included covering the square with wooden floor, however, it remained unimplemented due to financial shortages in the city budget. The Ethnographic Museum was not, however, in favour of this concept, considering it too ludicrous and im- 
posing one-sided interpretation of the historical square. Then museum decided to initiate programme activities on the square.

Katarzyna Piszczkiewicz, who coordinates museum activities in public space, admitted that "the modern city is organized in such a way, that people who live there can pass each other without collision. We are talking about the opposite about creating an opportunity to meet" (Jagodzińska 2020). In 2010 and 2018, the museum organised two major exhibitions at the square, consisting of large-scale wooden elements and structures by contemporary designers and craftsmen inspired by the museum collection. A variety of other activities were undertaken, including grassroot projects to paint benches and plant flowers in old unused pots. In 2018, due to safety reasons, an old tree - the only one providing shade near the entrance - had to be replanted. The museum planted a new tree and decided to add some seats. Ten volunteers were invited to participate in the project of designing new benches in cooperation with an artist. Even though it was a smallscale project, the museum clearly demonstrated intention to share responsibility for public space with people.

In 2019, the museum took another step forward and started to gather an informal group composed of various stakeholders from Wolnica Square and urban specialists, to work on the square development concept, so that the place could serve the residents. Piszczkiewicz refers to the museum in this regard as a "dialogue operator" and a "host of a good idea" (Interview with Katarzyna Piszczkiewicz 2019). The project is in its initial phase. The museum is building a catalogue of values, which is to constitute a set of arguments for discussion on the purpose and form of the square. The initiative aspires to be the reverse of the situation usually occurring with infrastructural projects, when neighbours and site users do not participate in the work at its planning stage, and public consultations are carried out about an almost finalised idea.

\section{Discussion on responsibility}

Projects in Warsaw and Kraków are underway, in Katowice the case is closed. Construction is in progress and once the whole area is built-up (it will most likely take several years), the post-industrial complex of the museum will be largely redefined. Although the museum was defeated, its actions started to raise awareness of the problem.

Katarzyna Jagodzińska published a major article on the post-industrial landscape of the Muzeum Śląskie versus the new housing estate and development of the city, in architectural monthly "Architektura \& Biznes", which provoked a debate among architects. It demonstrated no consent to the need to respect a context of the post-industrial landscape. The city authorities could introduce restrictions on the planned buildings' height with respect for history, identity and sustainable 
development, but they failed to do it. The regional authorities did not take a stand, nor did the museum's neighbours in the Cultural Zone. City residents do not have a sense of agency.

Professor Jacek Purchla, chairman of the Polish UNESCO Committee, commented: "In my opinion, today, it will not be possible to defend the cultural landscape with the help of paragraphs and restrictive provisions. To my understanding, the only cure for treating this disease is building a broad public awareness, raising consciousness of the value of this place" (Jagodzińska 2019b: 151). Indeed, it seems that this may be the role of museums.

All actions taken by museums, described in this article, prove that museums have a new role to play in today's cities, towns, neighbourhoods and communities. Considering the history of the new museology movement, that role is not "new" at all. However, examination of museum activities proves that the gap between theoretical considerations and adoption of those ideas in museum practice may be considerable. Active role of museums, as discussed in this article, may be seen as a response to the call raised by all museologists participating in museum discussions all over the world, from Mayrand and de Varine to Janes and Sandell.

Understandably, one should take into account regional differences between Latin America, North America, Europe, and Asia, where dynamics and nature of museums are related to local contexts and needs. Also, Europe should not be considered homogenous. Polish museums, especially the ones presented in the article, may surely be regarded emblematic in the discussion on breaking the monolith of traditionally managed museum set anywhere in the world, but they also grow from specific historical situation that makes tradition of museums and their social context much different than the one in France, the United Kingdom or Scandinavia.

Authors wanted particularly to focus on specific case studies and show various approaches to the responsibility of museums towards landscapes and various challenges that museum meet from the angle of the ICOM resolution. This is not a discussion on what new roles museums are taking, but on how they fulfil this particular new role. Discussions held by urban specialists, architects, activists, geographers, economists, and politicians regarding the civic right to the public space, might also offer context for these museological discussions.

Museums have become agendas for critical thinking, however, they not only give space for discussion, but also moderate discussions and take responsibility for issues connected to their subjects and identities. In Katowice, this connection between the nature of the dispute, i.e. safeguarding post-industrial landscape, and museum's identity is probably most obvious. Surprisingly, support of the citizens was not great in that case. In Wilanów, the matter is to stop or at least limit the consequences of civilization pressure, i.e. new infrastructural investments, noise and chaos, for the sake of the museum integrity and identity, but at the same time for the comfort of the district inhabitants. Here, the goals of both sides - museum 
and inhabitants - coincide. In Kraków, in both cases, museums have started to make efforts to improve quality of space adjoining the museum seats, which in effect is primarily intended for residents.

Should museums stand up and speak up? We believe there is no doubt about that. The question remains, however, to what extent it is possible? Are museums really free to do that? Will political, economic and social connections and tensions around museums allow museum directors to express their opinions freely and most importantly - take action regarding spaces outside museum headquarters? Museums have autonomy, but practice shows that excessive use of it costs directors their position (Knast was dismissed from the position of director in January 2020).

One could ask whether the Muzeum Śląskie could have done more to be successful? In this particular case, a pursuit of the city authorities to build high was in our view impossible to overcome. The developer and the architects have been operating within the frame that was offered by generous regulations instituted by city officials. But was it, indeed, a defeat? The museum raised an important issue that was widely discussed for the first time. The electric atmosphere of the discussion revealed how much there is still to be done in the field of raising public awareness on safeguarding and smart management of cultural heritage. Other case studies show that cooperation with groups and individuals having common ground is always beneficial and this is yet to be done in Katowice. However, without a leader that shares values introduced by the ICOM resolution, it is unlikely that the museum would follow this path.

The presented cases show that museums will undertake such activities, maybe even risking sometimes, although it would be highly desirable for them to have tools and support in their efforts. The resolution is a good, but - as we show not yet sufficient tool. It gives a mandate and encourages museums to play a new social role as a guardian of space, but broader recognition of museums as subjects that have a say regarding space around them is necessary. It is important to note that the ICOM resolution was taken as the argument by the Museum of King Jan III's Palace and the Muzeum Śląskie. The Ethnographic Museum refers to the UNESCO Recommendation on the Historic Urban Landscape, while the Museum of Podgórze - acknowledging the importance of the ICOM resolution - do not consider it is relevant, due to lack of cultural or landscape values of the area under the railway junction.

Organisers of the "Planning an Extended Museum" seminar held at the Museum of King Jan III's Palace at Wilanów in 2017, concluded that practical implementation of the 2016 resolution:

requires not only change of thinking in the museums themselves, but above all a great work to understand the new role these institutions can successfully play in protecting cultural and natural heritage and participation in social activities by the system of state administration, territo- 
rial self-governments, politicians and other decision-makers (Planowanie muzem w otoczeniu 2017).

Continuous education is a necessity. But so is taking an active position to demonstrate that the neighbourhood matters to museums. Thanks to activities for and/or with local communities, the voice of museums, previously ignored in public debate, absent from participatory activities, social environment, can be heard not only in matters of cultural environment.

\section{Bibliography}

Abramczyk S.

2016 Muzea na straży wartości przestrzeni publicznej, "PASSA Tygodnik Sąsiadów”, http://www.passa.waw.pl/artykul/muzea-na-strazy-wartosci-przestrzenipublicznej,10 92?ref=1 (access: 28.02.2020).

Brown K., Mairesse F.

2018 The Definition of the Museum Through Its Social Role, "Curator: The Museum Journal", vol. 61 (4), p. 525-539.

Council of Europe

2000 European Landscape Convention, Florence, European Treaty Series - No. 176.

Davis P.

1999 Ecomuseums: A Sense of Place, London-New York.

Garlandini A.

2017 ICOM Milan 2016: The New Responsibilities of Museums towards Landscapes, "Museum International", vol. 69, p. 164-175.

Hooper-Greenhill E.

2000 Museums and the Interpretation of Visual Culture, London.

Jagodzińska K.

2019a Museums and Centers of Contemporary Art in Central Europe After 1989, transl. Carolyn C. Guile, London-New York.

2019b Muzeum broni postindustrialnego krajobrazu, "Architektura \& Biznes", vol. 6, p. $142-153$.

2020 Obywatelski plac Wolnica, "Architektura \& Biznes" - Miasto na celowniku, 7 January, https://www.architekturaibiznes.pl/obywatelski-plac-wolnica,2967.html (access: 16.02 .2020$)$.

Janes R.R.

2010 The Mindful Museum, “Curator”, vol. 53 (3), p. 325-338.

Janes R.R., Sandell R.

2019 Posterity Has Arrived: The Necessary Emergence of Museum Activism in: R.R. Janes, R. Sandell (eds), Museum Activism, London-New York, p. 1-22.

Jaskanis P.

2016 Oświadczenie ws. budowy galerii handlowej w Wilanowie, https://www.wilanowpalac.pl/oswiadczenie_dyrektora_muzeum_ws_nieprawdziwej_informacji_ zamieszczonej_w_czasopismie_teraz_wilanow.html (access: 28.02.2020). 
Marstine J.

2006 Introduction in: J. Marstine (ed.), New Museum Theory and Practice. An Introduction, Malden-Oxford-Carlton.

Mayrand P.

2015 The New Museology Proclaimed, "Museum International", vol. 261-264, p. 115-118.

Mensch P. van

1995 Magpies on Mount Helicon in: M. Schärer (ed.), Museum and Community, ICOFOM Study Series 25, p. 133-138.

Museum definition

2019, https://icom.museum/en/activities/standards-guidelines/museum-definition/ (access: 12.02.2020).

Muzeum Śląskie

2007 Press release: Mamy projekt nowego Muzeum Śląskiego, 15 June 2007.

Planowanie muzeum w otoczeniu - sprawozdanie z międzynarodowego seminarium ICOM 2017,https://www.wilanowpalac.pl/planowanie_muzeum_w_otoczeniu_sprawozdanie_z_ miedzynarodowego_seminarium.html (access: 25.02.2020).

Resolutions Adopted by ICOM's $31^{\text {st }}$ General Assembly

2016 Milan, https://icom.museum/wp-content/uploads/2018/07/ICOMs-Resolutions_2016_Eng.pdf (access: 10.11.2019).

Twitter of the Silesian Museum

2018 Appeal to Prevent the Launch of Large Investments In the Immediate Vicinity of the Culture Zone and the Silesian Museum, 21 February.

UNESCO

2011 Recommendation on the Historic Urban Landscape, Including a Glossary of Definitions, http://portal.unesco.org/en/ev.php-URL_ID=48857\&URL_DO=DO_ TOPIC\&URL_SECTION=201.html (access: 10.02.2020).

Vergo P. (ed.)

1989 The New Museology, London.

Interviews

Interview with Katarzyna Piszczkiewicz, coordinator of activities in the public space in the Ethnographic Museum in Kraków, conducted on 22 August 2019 by Katarzyna Jagodzińska.

Interview with Maciej Żołnierczuk, PhD, specialist in landscape protection at the $\mathrm{Mu}$ seum of King Jan III's Palace at Wilanów, conducted on 14 November 2019 by Melania Tutak. 


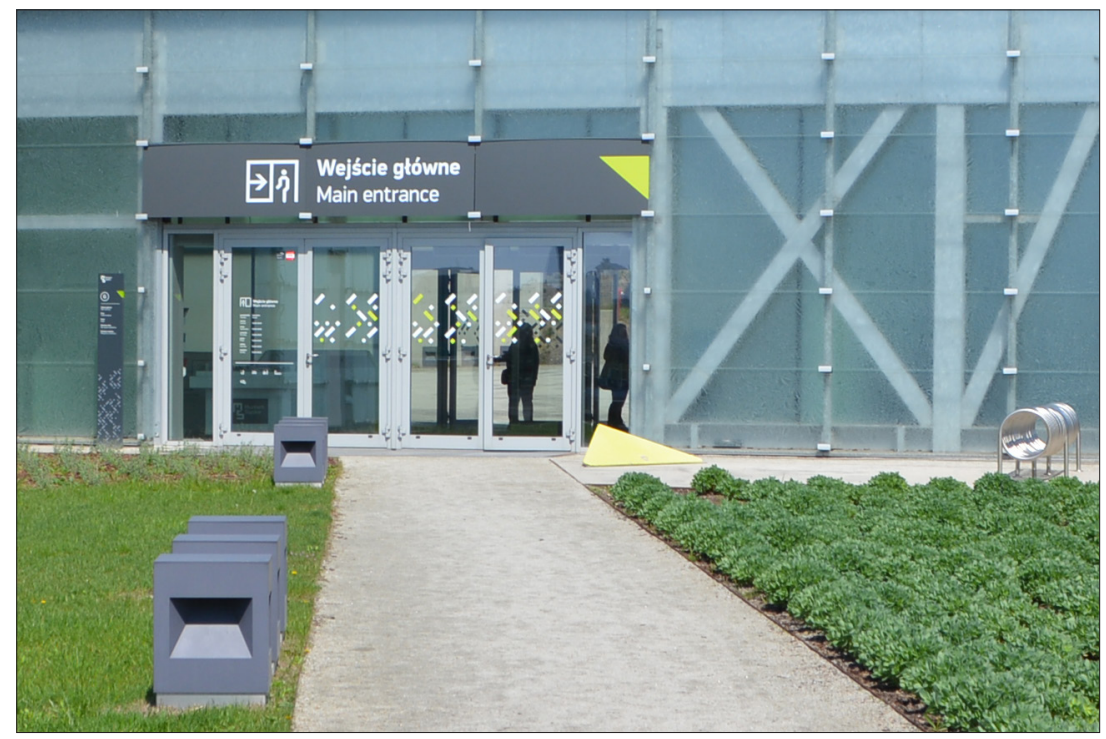

Illustration 1 Muzeum Śląskie in Katowice: interplay of historic mine buildings and new minimalist architecture. Photo Katarzyna Jagodzińska

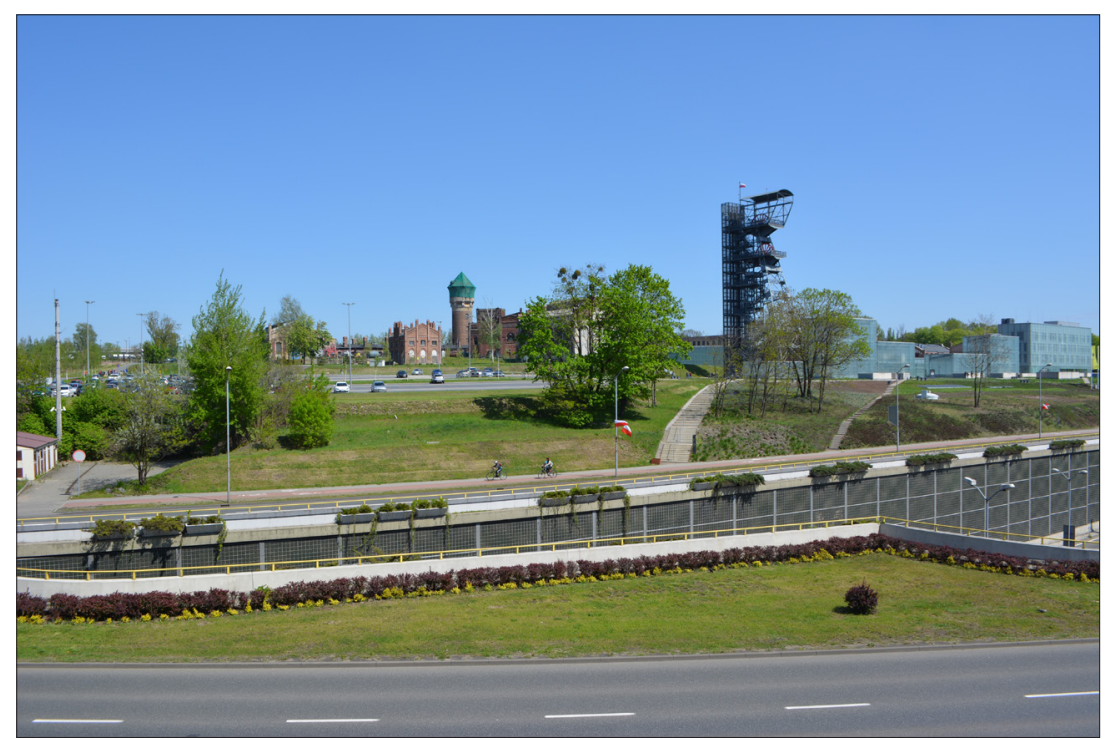

Illustration 2 View of the Muzeum Śląskie in Katowice from the footbridge leading to the museum from the city centre. In the foreground the hoist tower transformed into an observation tower, on the right the glass cubes, on the left historical mine buildings adapted to the museum functions

(revitalization is in process). Immediately behind the museum the new housing investment is being developed - tall blocks will constitute strong spatial presence (photo taken on 1 May 2019). 


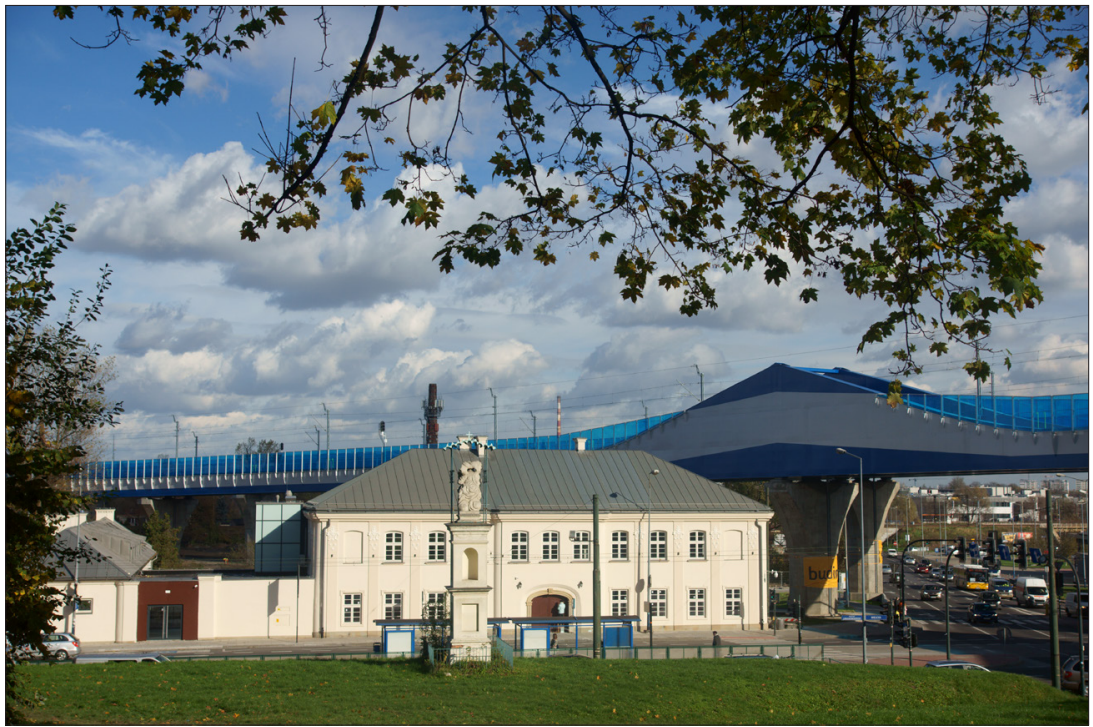

Illustration 3 Museum of Podgórze in Krakow located in the St. Benedict Inn. Behind the building the railway flyover. Photo Paweł Kubisztal

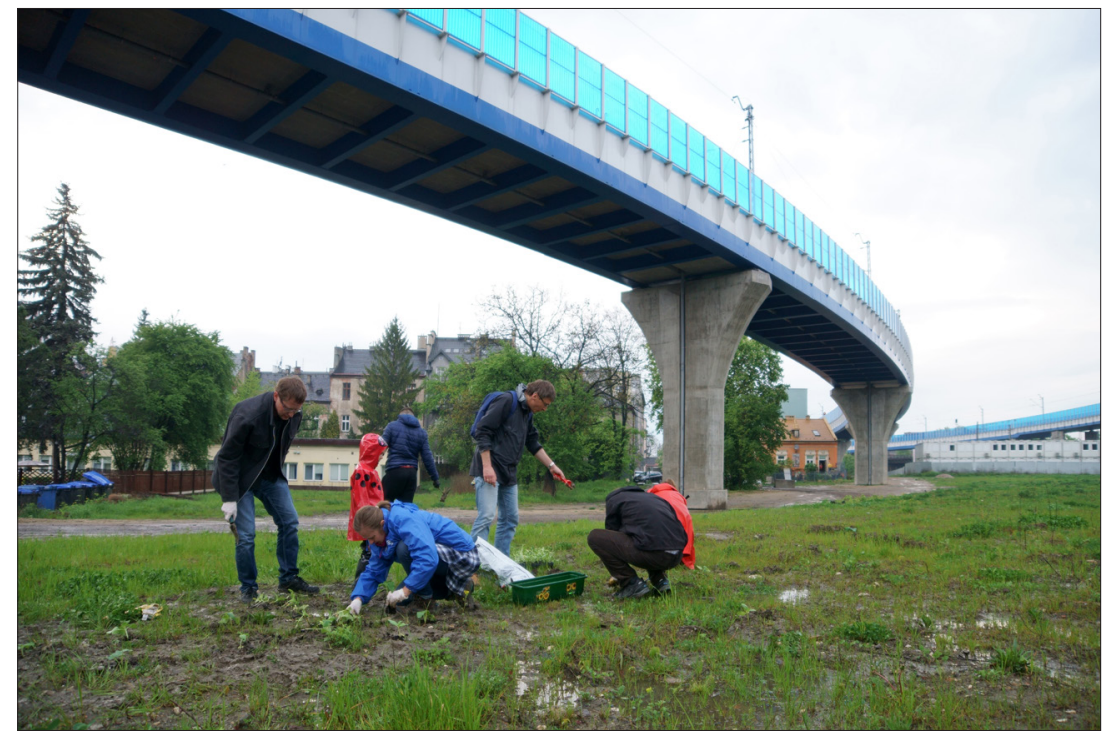

Illustration 4 Action of planting sunflowers under the railway flyover organized by the Museum of Podgórze in Krakow (30 April 2019). Photo Paweł Kubisztal 


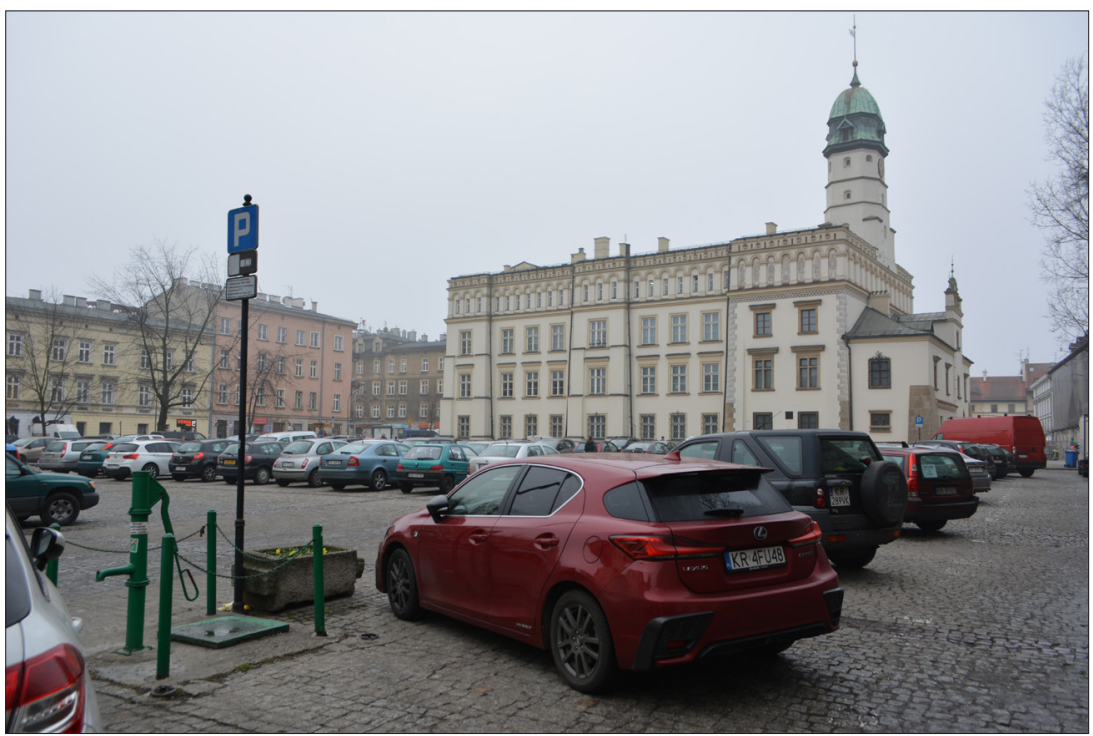

Illustration 5 Temporary parking lot at the Wolnica Square initiated in the beginning of 2019. View towards the Ethnographic Museum in Krakow. Photo Katarzyna Jagodzińska 